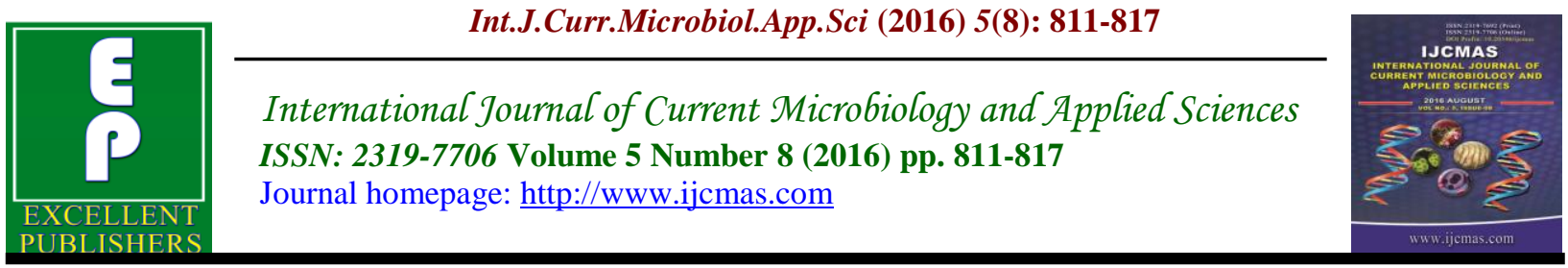

Original Research Article

http://dx.doi.org/10.20546/ijcmas.2016.508.090

\title{
Isolation and Identification of Bacteria Associated with Computer Keyboards and Mouse at Various Business Centres in Dutse Metropolis Jigawa State, Nigeria
}

\author{
R.H. Muhammad ${ }^{1}$, C.A. Yaro $^{2^{*}}$, B. Balarabe Musa $^{3}$ and S.B. Safiyya ${ }^{1}$ \\ ${ }^{1}$ Federal University, Dutse, Jigawa State, Nigeria \\ ${ }^{2}$ Kogi State University, Anyigba, Kogi State, Nigeria \\ ${ }^{3}$ University of Abuja, FCT Abuja Nigeria \\ *Corresponding author
}

\section{A B S T R A C T}

Keywords

Computer,

Keyboards,

Mouse,

Dutse.

\section{Article Info}

Accepted:

18 July 2016

Available Online:

10 August 2016
The present study was conducted to isolate and identify pathogenic microorganisms on the external surface of computer keyboards and computer mice. For this purpose, a total 60 samples were collected from different computer centres of Dutse, Jigawa State. The samples collected were cultured with Nutrient Agar and for further identification they were cultured on the selective media. All 60 samples were found contaminated with pathogenic bacteria (E. coli, B. licheniformis, E. aerogenes, B. epidermidis and Staphylococcus). S. aureus Gram-positive dominated the isolates. The second most common bacterial growth in all samples was $B$. epidermidis. Potential pathogens isolated from all results indicate that computer mouse and keyboards showed $100 \%$ Contaminated in comparison with other objects. The presence of pathogenic and commensal bacteria on these objects indicates that they might act as environmental vehicles for the transmission of potentially pathogenic bacteria.

\section{Introduction}

Computer is an electronic device that is used to accept process, analyze and give out an output. Computers continue to have an increased presence in almost every aspect of our occupational, recreational and residential environments. In various university environments, students have indicated $100 \%$ access to computers, $92.1 \%$ regularly use internet and $73.3 \%$ regularly use e-mail (Palmer and Bray, 2001). To accommodate the intensive use of computer technology, universities have developed multiple-user "Cyber Cafe" on campus for general student access. As the population of such facility increases, there is need to recognize that computer equipment may act as a reservoir for the transmission of potential hazardous or pathogenic bacteria (Hartman et al., 2004).

The ability of a computer to act as fomites has been previously documented in healthcare (Huber and Pelon, 2005) and hospital environment (Bures et al., 2000). In 
work place, contamination of the office environment (including the computer keyboard and mouse) with bacteria is also recognized (Hirsch, 2005). The increased availability of multiple-user computers in the university setting means that these items or equipment are handled by numerous users on a daily basis. Given that computers are not routinely disinfected, the opportunity for the transmission of contaminating bacteria is potentially great. Our understanding of the ubiquity of microorganism in the environment is developing, but the risk or hazard of contamination posed by the computer keyboards and mice is not yet fully understood. No clear regulations or even widely recognized guidelines have been formulated on the hazard caused by computer components (keyboards and mice). This is not in the best interest of campus students especially that computer keyboards and mice could spread significant number of pathogens.

Computers continue to have an increased presence in almost every aspect of our occupational, recreational and residential environments. Because of the mass use of the computers, there is need to recognize and identify whether the computer keyboards can act as a fomite and the possible way of contamination or transmission of infectious agents. The hygienic practices in the cyber café are far below expectations which could infer that users in these cyber café are almost ignorant or less informed of the risks involved in their usage of computers and that these surfaces could act as carriers or vehicles/sources of potential pathogens. If people are informed of the bacteria associated with computer keyboards and in our cyber café, it would help in reducing the risk of cross-transmission of bacterial infections through contaminated computer surfaces and would improve hygienic practices through regular and adequate disinfection of the surfaces. Therefore this research is designed to isolate and identify bacteria associated with computer keyboards, so as to be able to advise accordingly. This study aimed at isolating and identifying bacteria associated with computer keyboards and mice.

\section{Materials and Methods}

\section{Sample Collection}

Samples of computer keyboards were collected from computer keyboards at various business centers within Dutse metropolis. Sampling procedure was carried out as described by Cheesbrough (1984) and Baker and Slverton (1985). Sterilized swab stick pre-moistened with sterilized peptone water was taken to the sampling points. The cover of the swab stick was removed and the moistened cotton wool were rubbed on the computer keyboards (especially the most used keys i.e. shift, escape, backspace, delete, control keys) aseptically. The cover of the swab sticks were immediately replaced back taken to the laboratory for investigation.

\section{Media Preparation}

The media used were Nutrient agar and MacConkey agar, and were prepared according to the manufacturer's specification.

\section{Bacteriological Analysis}

All samples collected were inoculated into prepared Petri dishes containing media for isolation of bacteria. The medium used was general purpose media and differential media (i.e. MacConkey agar and Nutrient agar, respectively). The inoculated agar medium was incubated at $37^{\circ} \mathrm{C}$ for 24 hours. 
After incubation, colonies of organisms were counted and expressed as number as in colony forming unit per meter cube $\left(\mathrm{cfu} / \mathrm{m}^{3}\right)$.

\section{Gram Staining Principle}

Gram's staining was carried out to find the reactions of the bacteria isolated to Gram reagents. The stain divides the bacteria into two; Gram-positive bacteria, which takes up primary stain colour (crystal violet) and is stained blue and Gram-negative, which takes up the secondary stain colour (Safranin) and is stained red after decolourization with alcohol. The staining procedure was adopted as described by Cheesbrough (2006), Baker and Silverton (1985).

\section{Biochemical Test}

Identification of the isolated bacteria was carried out by first observing the appearance of the colonies produced which was followed by Gram's staining and subsequent subculture onto slant bottles of Nutrient agar. Biochemical tests such as Catalase, coagulase, indole, Citrate, urease, Methyl Red test (MR), sugar fermentation, $\mathrm{H}_{2} \mathrm{~S}$ production, were carried out on the isolated bacteria (Oyeleke and Manga, 2008).

\section{Results and Discussion}

The result of isolation and identification of bacterial count isolates were presented in the tables below. Table 1 indicated the morphological and biochemical characteristics of bacteria isolated from the study. It was observed that Staphylococcus species have the highest incidence of occurrence, Bacillus species and Enterobacter species have equal incidence of occurrence with Escherichia coli having the least incidence of occurrence. Table 2 shows that Staphylococcus aureus had the highest percentage frequency of occurrence of $40 \%$, Bacillus licheniformis and Enterobacter aerogenes have equal number of percentage frequency of occurrence of 21\%. Meanwhile Escherichia coli and Staphylococcus epidermidis have the least percentage frequency of occurrences of $7 \%$ and $12 \%$ respectively.

The present study reported highest incidence of Staphylococcus species with percentage frequency of occurrence of $39.0 \%$. This result is inconformity with the result obtained by Sharri et al. (1991), who reported Staphylococcus aureus as the highest bacteria isolated from their study. The highest percentage frequency of occurrence of Staphylococcus aureus could be due to the ability of the organism to withstand the effect of radiation emitted by the computer. Because computer was known to emit radiation which is lethal to the microorganisms or it could be that the radiation emitted by the computer is not enough to cause any lethal effect on Staphylococcus aureus. Also this could be due to the fact that Staphylococcus aureus is abundant in the human body especially skin as a normal flora. However, it has been reported that Staphylococcus aureus as nasal carriage occurs in $40-50 \%$ of humans (Cheesbrough, 1984).

The result of bacteria isolated from the computer keyboards as presented in Tables 2 correspond to previous studies that computer keyboards and mice can become contaminated with pathogenic bacteria (Cozanitis et al., 1978; Rafferty and Pancoast; 1984; Ferdinandus et al, 2001, Anderson and Palombo, 2009). The present study showed that bacterial contamination that occur on computer surfaces may reflect the multiple-user environment where the possibility of contamination by individuals who are carriers of bacteria is greater and 
Table.1 Morphological and Biochemical characteristics of the bacterial isolate from the samples collected

\begin{tabular}{|c|c|c|c|c|c|c|c|c|c|c|c|}
\hline $\begin{array}{c}\text { Gram } \\
\text { staining }\end{array}$ & Catalase & Coagulase & Lactose & Glucose & Sucrose & Citrate & Indole & Urease & $\mathbf{H}_{2} \mathrm{~S}$ & Gas & Organisms Identified \\
\hline $\mathrm{G}+\mathrm{ve}$ cocci & + & - & - & + & + & - & + & + & - & + & Staphylococcus epidermidis \\
\hline G + ve Rod & + & - & + & + & + & + & - & - & - & + & Baccillus licheniformins \\
\hline G -ve rod & - & - & - & + & - & - & - & + & - & - & Escherichia coli \\
\hline $\mathrm{G}+\mathrm{ve}$ cocci & + & + & + & + & + & - & - & + & - & + & Staphylococcus aureus \\
\hline $\mathrm{G}$-ve rod & - & - & + & + & + & + & - & - & - & + & Enterobacter aerogenes \\
\hline $\mathrm{G}+\mathrm{ve}$ rod & + & - & + & + & + & + & - & - & - & + & Baccillus licheniformins \\
\hline G -ve rod & - & - & + & + & + & + & - & - & - & + & Enterobacter \\
\hline
\end{tabular}

Key + = positive - = Negative, G+ve $=$ Gram positive $\mathbf{G}$-ve $=$ Gram Negative $\quad \mathbf{H}_{2} \mathbf{S}=$ Hydrogen sulphide

Table.2 Percentage frequency of occurrences of the isolated bacteria

\begin{tabular}{lc}
\hline Bacteria & Percentage (\%) of Occurrences \\
\hline Staphylococcus epidermidis & $12.00 \%$ \\
Bacillus licheniformis & $21.00 \%$ \\
Staphylococcus aureus & $39.00 \%$ \\
Enterobacter aerogenes & $21.00 \%$ \\
Escherichia coli & $7.00 \%$ \\
Total Percentage & $\mathbf{1 0 0 \%}$ \\
\hline
\end{tabular}


the isolation of viable microorganisms suggest that the species present are able to persist for a period of time on these surfaces. It is suggested that computer keyboards and mice in institutions may act as a vehicle for the transmission of pathogenic organisms (Anastasiades et al., 2009).

In this study, Staphylococcus aureus was isolated from all the cyber café and this bacterial isolate is of medical importance as a causative agent of human diseases. It has been known to cause various pus-forming infections in humans such as boils, carbuncles, impetigo, osteomyelitis, toxicshock syndrome (Hartman et al., 2004). On the other hand, Staphylococcus epidermidis which was also isolated from most of the samples is a normal inhabitant of the skin but can occasionally assume an opportunistic pathogenic role in causing human infection such as endocarditis (Anastasiades et al., 2009). Most of the samples indicated that Enterobacter, Bacillus and E. coli species can also be spread in the cyber café through surfaces such as computer keyboards. Isolation of the organisms from computer keyboards is a clear indication that the aseptic procedures/methods in use at the computer centers are not effective in reducing the level of the organisms on these surfaces to an acceptable level (Buers et al., 2000).

This situation calls for both private and government agents in the public health sector to awake to their responsibilities in sensitizing the public through organizing lectures, training workshops and seminars of the potential risk involved in the use of contaminated computer surfaces in the cyber café. If people are informed of the microorganisms associated with computer keyboards and in our cyber café, it would help in reducing the risk of crosstransmission of bacterial infections through contaminated computer surfaces and would improve hygienic practices through regular and adequate disinfection of the surfaces. Government, through the appropriate agencies, should also set standard for the cyber café operators and monitor the practices in such cyber café from time to time as this will go a long way in helping to reduce microbiological and other hazards associated with cyber café and computer centers.

It was observed that the level of knowledge among the computer users in cyber café and computer centers about the possibility of microorganisms on the keyboard is very poor. Majority of the computer users do not have any perception of the unhealthy practices in cyber café and possibly not aware of the risk of contracting infection from computer keyboard and mouse through such use. In every cyber café, eating should be avoided while using the computers and hand washing hygiene practices should be encouraged and maintained and keyboard and mice should be cleaned with disinfectant at least weekly and should be covered where necessary. The process of disinfection is to reduce microbial load on the solid surfaces. Microbes are everywhere, including the air around us, it is therefore greatly recommended that hand-washing hygiene should be adopted before and after using the computers to reduce the microbial transmission. Computer keyboards and mice should also be cleaned with alcohol or other disinfectants on a regular basis.

In conclusion, improvement in science and technology brings about massive utilization of computers which help to reduce difficulties in most working places nowadays. Computer keyboards have long been suspected to be an agent of microbial dissemination. The microbes suspected to be disseminated by computer keyboards can be both pathogenic and non-pathogenic (Halpen et al., 1995). Five genera of 
organisms have been isolated from the study namely Staphylococcus aureus, Staphylococcus epidermidis, Bacillus licheniformis, Enterobacter and E. coli. And these organisms can cause different diseases to the computer users. The results obtained in this study encourages further studies in the isolation and identification of bacteria associated with computer keyboards this will help to better understand the incidence of bacteria associated with computer keyboards and enable the users to take adequate measures ins topping the spread of infection through computer keyboards.

\section{Recommendations}

The computer users should wash their hands with detergent or any other antiseptic agent before and after using the computer.

\section{References}

Anderson, G., and Palombo, E.A. 2008. Microbial contamination of computer keyboards in a university setting; American J. Infect. Control, 37(6) pp.507-9.

Buers, S., Fishbain, J.T, Uyehara, C.F.T., Parker, J.M., Berg, M.W. 2000. Computer keyboards and faucet handles as reservoirs of nosocomial pathogens in the intensive care unit. Am. J. Infect. Control, 28: 465-470.

Chris, Y. 1999. Where would I find out what types of bacteria grow on computer keyboards. Mad. Sci. Network. Microbiol., I.D 924233370.

Criswell, D.F., Parchaman M.L. 2003. Handheld computer use in U.S Family Practice Residency programs. $J$. American Information Association, 1: 80-6.

David, J.W., and William, A.R. 2002. Formites Role in Diseases Transmission Surgical Center Las Vegas NV Med mined, 7(1): 62-69.
Fukata, T. 2008. Anesthetists' Role in computer keyboard contamination in an operating room, J. Hosp. Infect., 22: $23-25$.

Garba, C. 2002. Attachment of staphylococcus to different plastic tubes in vitro. J. Med. Microbiol., 40(1): 37-42.

Halpen, W.A., Burnett, G. and Morgan, S., 1995. Remote communication from a mobile terminal: an adjunct for a computerized intensive care unit order management system .Critical Care on Med., 23(12): 2054-7.

Hartman, B. 2004. Computer Keyboard and Mouse as a Reservoir of Pathogens in an Intensive Care Unit., J. Clin. Monitoring, 18: 7-12.

Kramer. 2006. Licensee Bio. Med. Central Ltd., How long do nosocomial pathogens persist on inanimate surfaces? A systematic review. $B M C$ Infect. Dis., 6:130., http://www.biomedcentral.com/14712334/6/130.

Michael, B. 2002. Cross- contamination commercial facilities can be overloaded breeding ground for diseases. The Information Resource for the Cleaning Industry. KENT Commercial Floor Care Product, pp. 1-7.

Micheal, J.P., Chan, E.C.S., and Noel, R.K. 2000. Microbiology $5^{\text {th }}$ Ed. Tata McGraw-Hill Publishing Co. Limited New Delhi, pp261-285.

Palmer, S.R., Bray, S.L. 2001. Longitudinal study of computer usage in flexible engineering education. Australian $J$. Edu. Tech., 17: 313-314.

Reuter, K. 2005. Hospital keyboard can spread germs .A nursing perspective. Top health Information Management; 14(4): 24-9.

Rusin, P., Maxwell, S., Gerba, C. 2002. Comparative surface-to-hand and 
finger tipto- mouth transfer efficiency of gram positive bacteria, gram negative bacteria, and phage. J. Appl. Microbiol., 93: 585-592.

Rutala, W. 2006. Bacterial Contamination of Keyboards: Efficacy and Functional Impact of Disinfectants. Infect. Control and Epidemiol., Vol. 27

Schultz, M. 2006. Bacterial Contamination of Computer Keyboards in a Teaching Hospital, Infect. Control and Hosp. Epidemiol.

Sharri, M., Criswell, D.F., Parchman, M.L., Dick, R., and Steen, E.B. 1991. The computer based patient record: an essential technology for health care committee on improving the patient record. Institute of Medicine, National Academy Press Washington D.C.

William, A., Rutala, Susan, L., Barbee, Newman, C., Aguiar, Mark D., Sobsey, David, J., Weber. 2002. "Antimicrobial Activity of Home Disinfectants and Natural Products against Potential Human Pathogens". Infect. Control and Hosp. Epidemiol., (The University of Chicago Press on behalf of The Society for Healthcare Epidemiology of America) 21(1): 3338.

\section{How to cite this article:}

Muhammad, R.H., C.A. Yaro, B. Balarabe Musa and Safiyya, S.B. 2016. Isolation and Identification of Bacteria Associated with Computer Keyboards and Mouse at Various Business Centres in Dutse Metropolis Jigawa State, Nigeria. Int.J.Curr.Microbiol.App.Sci. 5(8): 811-817. doi: http://dx.doi.org/10.20546/ijcmas.2016.508.090 